\title{
The analyses of the phenomena inside a CNG flap-valve injector during gas flow
}

\begin{abstract}
The paper describes simulation tests of a gas injector with the use of numerical fluid mechanics. The tests were carried out on a CNG flap-valve injector which was connected with an inlet manifold by an additional injection pipe. Such a model was identified and calibrated on the basis of the test stand research. The paper presents the tests results in transient conditions (during valve opening and closing) and in a steady-state flow. The analysis concerns pressure and gas velocity flow in selected points and sections of the injector and the injection pipe. The processes occurring in selected areas of the injector have been presented. Moreover, areas essential for the useful characteristics of the injector have been illustrated.
\end{abstract}

Key words: injector, simulation tests, CNG - Compressed Natural Gas, CFD - Computational Fluid Dynamics

\section{Analiza zjawisk związanych z przepływem gazu CNG przez wtryskiwacz o konstrukcji klapowej}

\begin{abstract}
W artykule opisano badania symulacyjne wtryskiwacza gazu metoda numerycznej mechaniki płynów. Badania przeprowadzono na modelu wtryskiwacza klapowego zasilanego CNG, połaczonego z kolektorem dolotowym dodatkowym przewodem wtryskowym. Opracowany model zostat zidentyfikowany $i$ wykalibrowany na podstawie badań stanowiskowych. Przedstawiono wyniki badań w stanie nieustalonym (podczas otwierania i zamykania wtryskiwacza) oraz w czasie ustalonego przepływu. Analizie poddano ciśnienia i prędkości przepływu gazu w wybranych punktach oraz przekrojach wtryskiwacza i przewodu wtryskowego. Przedstawiono zjawiska zachodzace w wybranych przekrojach wtryskiwacza. Wskazano także przekroje istotne dla charakterystyki użytecznej wtryskiwacza.
\end{abstract}

Słowa kluczowe: wtryskiwacz, badania symulacyjne, gaz ziemny, CFD

\section{Introduction}

Both LPG and CNG are popular alternative fuels used in SI engines. This fact results from the price difference between these fuels and gasoline. A fuel delivery system for such fuels requires the engine to be fitted with an additional system being a dependent one which is a copy of a classic fuel injection system. An engine fitted with such a system must meet ecological requirements identical as is in the case of an engine fitted with a regular fueling system (gasoline). To fulfill these requirements fuel dosage must be very accurate. As it was mentioned in [6] the element having a significant influence on the accuracy is the gas injector. It should both enable a proper repeatable fuel dosage and be characterized by a linear dependency of capacity in the opening time function.

In order to obtain a design satisfying such assumptions it is essential to analyze the flow processes occurring inside the injector and having an impact on the characteristics of the mass flow in the injection time function. It is obtainable via Computational Fluid Dynamics (CFD). An effective use of such numerical techniques in examining gas injections is described in $[2,3,5]$. This method does not interfere in the construction of the examined object, therefore it does not affect the processes occurring inside the object $[6,1]$. It also enables checking of the influence of the changes in

\section{Wprowadzenie}

Zarówno LPG, jak i CNG są popularnymi paliwami alternatywnymi stosowanymi do zasilania silników spalinowych. Wynika to przede wszystkim z mniejszych ich cen niż benzyny. W silnikach o zapłonie iskrowym zasilanie to wymaga wyposażenia silnika w dodatkowy układ kopiujący sterowanie wtrysku benzyny, będący układem zależnym. Tak wyposażony silnik musi spełniać wymania ekologiczne identyczne jak silnik zasilany paliwem podstawowym (benzyną). Aby spełnić te wymagania konieczne jest precyzyjne dawkowanie paliwa. Jak opisano w pracy [6], elementem mającym istotny wpływ na tę precyzję jest wtryskiwacz gazu. Powinien on zapewnić powtarzalne podawanie określonej dawki paliwa, jak również charakteryzować się liniową zależnością wydatku w funkcji czasu otwarcia.

Aby otrzymać konstrukcję spełniającą takie założenia, konieczne jest poznanie zjawisk przepływowych, zachodzących wewnątrz konstrukcji wtryskiwacza i mających wpływ na charakterystykę masowego natężenia przepływu w funkcji czasu wtrysku. Możliwe jest to przy wykorzystaniu numerycznej mechaniki płynów (CFD). Efektywne wykorzystanie tego typu technik obliczeniowych do badania procesu wtrysku gazu zostało opisane w pracach $[2,3,5]$. Metoda ta nie ingeruje $\mathrm{w}$ budowę badanego obiektu, a zatem nie zaburza zjawisk w nim zachodzących $[6,1]$. Umożliwia 
the design on the injector operation without the necessity of building a prototype.

This paper is the continuity of the issue presented in [6] which illustrates the process of preparation of a CNG injector model. At this stage, flowing processes were analyzed. Moreover, during the calculation the element connecting the injector with the inlet manifold (injection pipe) was considered.

\section{Injector model}

The analyzed model is based on serial-production gas injector (Fig. 1) The distinctive feature of this design is the use of a flap valve lifted by an electromagnetic coil and closed by a spring (Fig. 2). The rubber element is attached to the top body of a valve which functions as a seal. The capacity regulation of the injector is realized through the change of an injection nozzle diameter [6].

The model, based on real geometry, was constructed in a CAD program. The next step was establishing the discretization and the initial and boundary conditions in a Star-CD program [4].

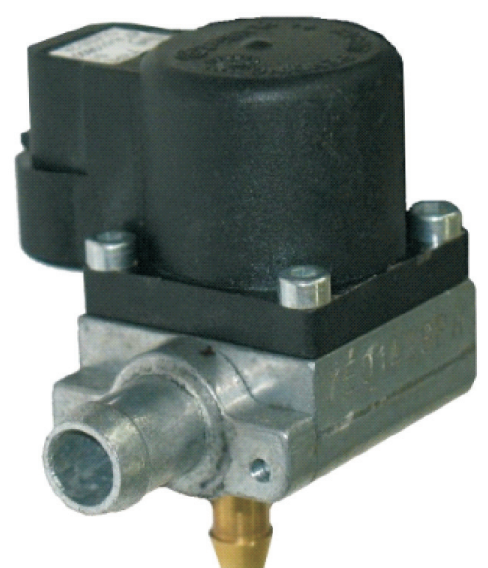

Fig. 1. Flap valve injector [5] Rys. 1. Klapowy wtryskiwacz gazu [5]

Initial and boundary conditions were accepted from [6]:

a) input pressure of the gas injector was adopted as the pressure time-course from the test stand research of mean value $200 \mathrm{kPa}$ (Fig. 4, green line $>250 \mathrm{kPa}$ );

b) pressure in the inlet manifold was adopted as the pressure time-course from the test stand research of mean value 65 $\mathrm{kPa}$ (Fig. 4, blue line);

c) gas temperature $303 \mathrm{~K}$;

d) adiabatic walls of the injector and the injection pipe (lack of heat exchange with the medium);

e) gas flow density depends on the pressure and the temperature;

f) in the injector methane was used as a medium. It is characterized by:

- density in normal conditions $0.65687 \mathrm{~kg} / \mathrm{m}^{3}$

- dynamic viscosity $1.119 \cdot 10^{-5} \mathrm{~kg} / \mathrm{m} \cdot \mathrm{s}$

- specific heat $2240.07 \mathrm{~J} / \mathrm{kg} \cdot \mathrm{K}$

- heat conductivity $0.0348195 \mathrm{~W} / \mathrm{m} \cdot \mathrm{K}$

- molecular weight $16 \mathrm{~kg} / \mathrm{kmol}$. natomiast porównanie wpływu zmian konstrukcyjnych na pracę wtryskiwacza bez konieczności budowy kolejnych prototypów.

Niniejsza praca jest kontynuacją zagadnienia przedstawionego w artykule [6], w którym omówiono proces przygotowania modelu wtryskiwacza CNG. W tym etapie badań analizie poddano zjawiska przepływowe. Podczas obliczeń uwzględniono również element łączący wtryskiwacz z kolektorem dolotowym (przewód wtryskowy).

\section{Model wtryskiwacza}

Analizowany model wtryskiwacza oparto na seryjnym wtryskiwaczu gazu (rys.1). Cechą charakterystyczną tej konstrukcji jest zastosowanie zaworu klapowego podnoszonego przez cewkę elektromagnetyczną i zamykanego przez sprężynę (rys. 2). Do powierzchni zaworu przymocowany jest element gumowy stanowiący uszczelnienie. Regulacja wydatku wtryskiwacza realizowana jest przez zmianę średnicy dyszy wtryskowej [6].

Na podstawie rzeczywistej geometrii opracowano model w programie CAD. Następnie przeprowadzono dyskretyzację, założono warunki początkowe oraz brzegowe w programie Star-CD [4].

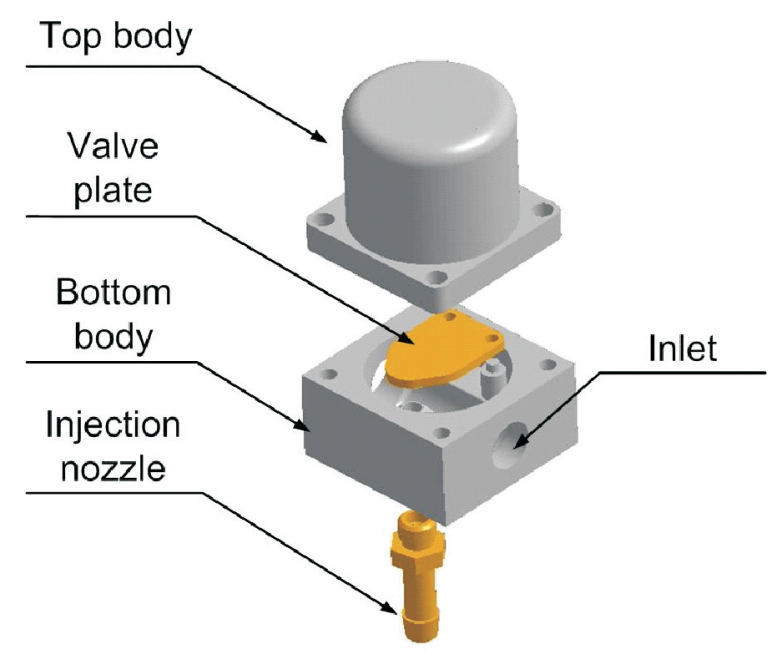

Fig. 2. Injector components [5]

Rys. 2. Elementy sktadowe wtryskiwacza [5]

Warunki początkowe oraz brzegowe modelu przyjęto z pracy [6]:

a) ciśnienie zasilania gazem wtryskiwacza przyjęto jako przebieg ciśnienia $\mathrm{z}$ badań stanowiskowych o wartości średniej równej $200 \mathrm{kPa}$ (na rys. 4 linia zielona $>250$ $\mathrm{kPa}$;

b) ciśnienie w kolektorze dolotowym przyjęto jako przebieg ciśnienia z badań stanowiskowych o wartości średniej równej $65 \mathrm{kPa}$, (rys. 4, linia niebieska);

c) temperatura gazu równa $303 \mathrm{~K}$;

d) adiabatyczne ścianki wtryskiwacza i przewodu wtryskowego (brak wymiany ciepła z czynnikiem);

e) gęstość przepływającego gazu zależna jest od ciśnienia i temperatury; 
The next step was the model calibration in the assumed conditions and as a result conformity of the simulation tests and test stand research was achieved. The calibration included the characteristics of the flap valve movement (Fig. 3), the opening and closing lag (Fig. 4) and the flow resistance through individual elements.

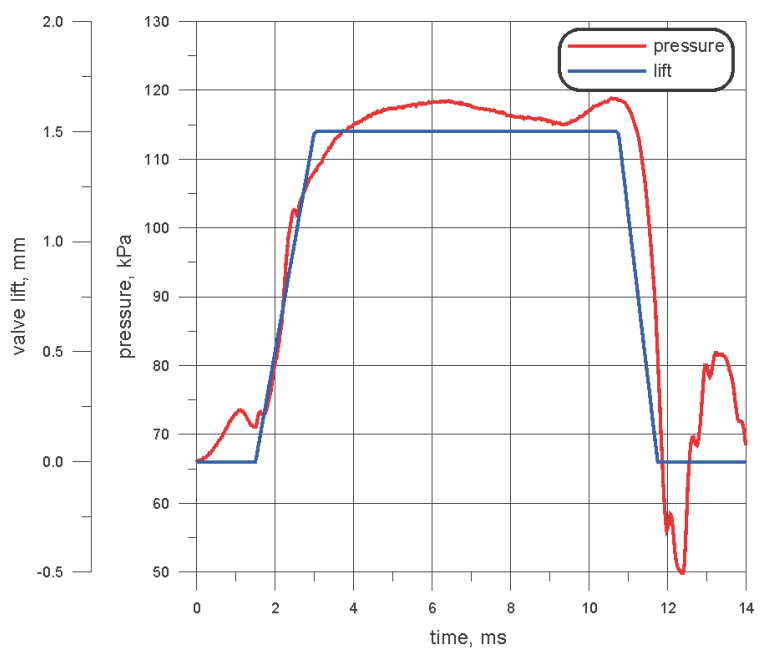

Fig. 3. Characteristics of the opening of the flap valve injector in comparison to the pressure in the inlet pipe [5]

Rys. 3. Charakterystyka otwarcia zaworu klapowego wtryskiwacza na tle ciśnienia w przewodzie wtryskowym [5]

\section{The scope of research}

Simulation tests concerned a single gas injection into the inlet manifold. The calculation period included one engine work cycle at the engine speed of $2800 \mathrm{rpm}$ (cycle time was $42 \mathrm{~ms}$ ) and the gas injection (control signal) started at TDC induction stroke and lasted for $9.1 \mathrm{~ms}$ (Fig. 4).

The pressure distribution and gas velocity were analyzed in selected points of the injector: gas inlet, space under the flap valve, injection nozzle, injection pipe (about $60 \mathrm{~mm}$ from the flap valve) and injection pipe in a connection point with the inlet manifold. Additionally, the pressure distribution and gas flow velocity were tested in two perpendicular planes: A-A, B-B (Fig. 5).

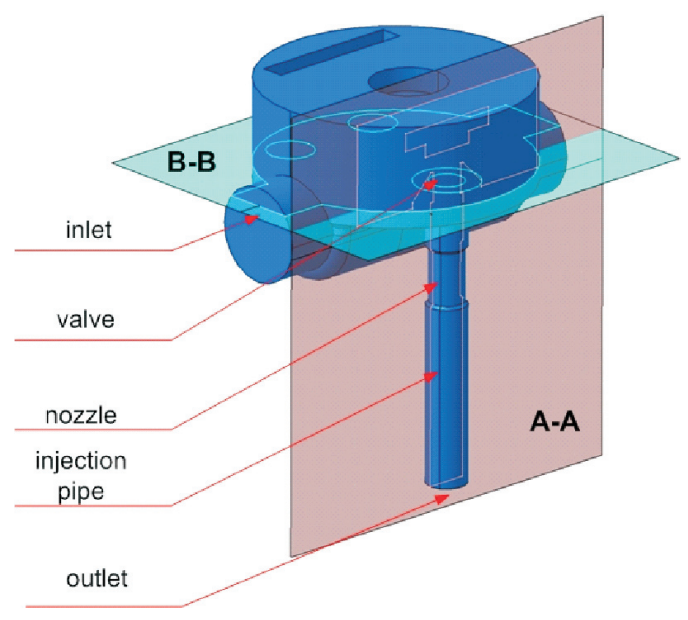

Fig. 5. Measuring points and analyzed planes

Rys. 5. Punkty pomiarowe oraz analizowane płaszczyzny przekroju f) przez wtryskiwacz przepływa metan o właściwościach:

- gęstość w warunkach normalnych $0,65687 \mathrm{~kg} / \mathrm{m}^{3}$

- lepkość dynamiczna $1,119 \cdot 10^{-5} \mathrm{~kg} / \mathrm{m} \cdot \mathrm{s}$

- ciepło właściwe $2240,07 \mathrm{~J} / \mathrm{kg} \cdot \mathrm{K}$

- przewodność cieplna 0,0348195 W/m·K

- ciężar molekularny $16 \mathrm{~kg} / \mathrm{kmol}$.

Dla tak założonych warunków wykonano kalibrację modelu [6], uzyskując zgodność wyników badań symulacyjnych ze stanowiskowymi. Kalibracja obejmowała charakterystykę ruchu zaworu klapowego (rys. 3), czas opóźnienia i zamykania (rys. 4) oraz opory przepływu przez poszczególne elementy.

\section{Zakres badań}

Przeprowadzono badania symulacyjne jednego wtrysku gazu do kolektora dolotowego silnika. Okres obliczeń obejmował jeden pełny cykl pracy silnika przy prędkości obrotowej $2800 \mathrm{obr} / \mathrm{min}$ (czas trwania cyklu wynosił $42 \mathrm{~ms}$ ), przy czym wtrysk gazu (sygnał sterujący) rozpoczynał się w GMP suwu dolotu i trwał 9,1 ms (rys. 4).

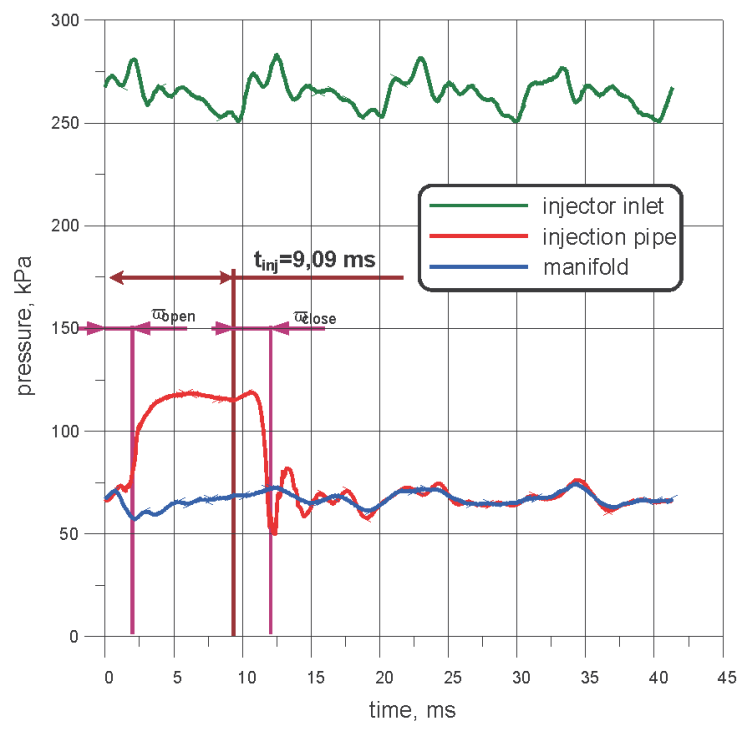

Fig. 4. Pressure course in selected points of the system - test bed research

Rys. 4. Przebiegi ciśnień w charakterystycznych punktach układu - badania stanowiskowe

Analizie poddano przebiegi ciśnienia oraz prędkości gazu w wybranych punktach wtryskiwacza: wlot gazu, przestrzeń pod zaworem klapowym, dysza wtryskowa, przewód wtryskowy (około $60 \mathrm{~mm}$ od zaworu klapowego) oraz przewód wtryskowy w miejscu połączenia z kolektorem dolotowym silnika. Dodatkowo przeanalizowano rozkład ciśnienia i prędkości przepływu gazu w dwóch prostopadłych do siebie płaszczyznach przekroju: A-A, B-B (rys. 5).

\section{Wyniki badań i analiza wyników}

Na rysunkach 6a oraz 7a przedstawiono przebiegi ciśnienia oraz prędkości przepływu gazu w analizowanych punktach wtryskiwacza w funkcji czasu. Analizie poddano jeden pełny cykl pracy silnika. Sygnał wtrysku rozpoczynał się w $0 \mathrm{~ms}$ (linia fioletowa, rys. 6a) i trwał do 9,1 ms. 


\section{Test results and analysis}

Fig. $6 a$ and $7 \mathrm{a}$ illustrates the pressure and gas flow velocity at the analyzed points of the injector in a time line. The whole single cylinder cycle was considered. Injection control signal started at $0 \mathrm{~ms}$ (purple line, Fig. 6a) and lasted through $9.1 \mathrm{~ms}$.

The pressure course measured at the pipe outlet (green line Fig. 6a) during its opening time is compatible with the experiment results [6]. The pressure increase in the selected points occurs together with a lag in comparison to the injector control signal (purple line, fig 6a) which is the opening injection lag of $1.5 \mathrm{~ms}$ in this case.

In order to analyze the injector opening process, a time range was narrowed from $1 \mathrm{~ms}$ to $3 \mathrm{~ms}$ (Fig. $6 \mathrm{~b}$ and $7 \mathrm{~b}$ ).

When analyzing the gas flow velocity (Fig. 7b) one can notice a slight fuel leak from the gas pipe (orange line Fig. 7b) when the injector is still closed (from 1.0 through $1.5 \mathrm{~ms}$ ) - the gas flow velocity at the pipe outlet reaches approx. $50 \mathrm{~m} / \mathrm{s}$. It results from a momentary difference of pressure in the inlet manifold and the gas pipe (pressure oscillation resulting from the cycle engine induction). It is also seen, but to a smaller degree, that at the test point in the gas pipe (green line Fig. 7b) where the gas flow is much slower - the velocity is $13 \mathrm{~m} / \mathrm{s}$.

At the point of real injection opening - at $1.5 \mathrm{~ms}$, an almost simultaneous gas flow through the valve and the nozzle is observed. Velocity (Fig. 7) below the valve and in the injection nozzle is similar at $1.7 \mathrm{~ms}$. After $0.3 \mathrm{~ms}$ from the start of the flow $(1.8 \mathrm{~ms})$ the gas flows to the end of the injection pipe.

After another $0.6 \mathrm{~ms}$ ( $2.4 \mathrm{~ms}$ from the start of the control signal) a stabilization of the gas flow through the system takes place (Fig. 6 and 7). It is seen through the pressure stabilization at selected test points as well as in the flow velocity. The gas flows with high velocity achieving $430 \mathrm{~m} / \mathrm{s}$ at the nozzle, $300 \mathrm{~m} / \mathrm{s}$ at the valve and $210 \mathrm{~ms}$ at the test point in the gas pipe. Simultaneously, we notice that in the pipe the gas expands (pressure drop between the test point and the pipe outlet) and, what follows, is the gas acceleration which at the pipe outlet (inlet to the manifold) reaches $355 \mathrm{~ms}$.

During a period from $6 \mathrm{~ms}$ through $10 \mathrm{~ms}$, corresponding to the final stage of the stable injector opening one can notice a drop in the pressure and flow velocity inside the injector (blue line Fig. 6a and 7a). It is probably a result of the pressure drop at the injector inlet. It is an effect of too small a volume of the pipes supplying gas to the injector and the wave phenomena occurring in this pipe as a result of cyclic valve operation or both these processes at the same time.

Similarly as is in the case of the opening, the time lag of $2.0 \mathrm{~ms}$ is observed during the injector closing. The beginning of the flap movement starts at $1 \mathrm{~ms}$ from the turning off of the control signal, which is seen in the local minimum pressure below the valve (blue line, Fig. 6c). This lag results from the time needed to discharge the energy collected in the coil.

The following pressure increase at this point is an effect of the flap movement towards the valve. The maximum of these increase appears in the moment of the valve closing i.e. $1.7 \mathrm{~ms}$ past the moment of the switching off of the control signal.
Przebieg ciśnienia zmierzony na wyjściu z wtryskiwacza (linia zielona, rys. 6a) w okresie jego otwarcia jest zgodny z wynikami badań eksperymentalnych [6]. Wzrost ciśnienia w poszczególnych punktach pomiarowych następuje z pewnym opóźnieniem w stosunku do sygnału otwarcia wtryskiwacza (linia fioletowa, rys. 6a) co stanowi opóźnienie otwarcia wtryskiwacza wynoszące w tym przypadku około 1,5 ms.

W celu przeprowadzenia dokładnej analizy procesu otwierania wtryskiwacza zakres czasowy zawężono do przedziału od $1 \mathrm{~ms}$ do $3 \mathrm{~ms}$ (rys. 6b, 7b).

Analizując przebieg prędkości wypływu gazu (rys. 7b), można zauważyć zjawisko nieznacznego wypływu paliwa z przewodu gazowego (linia pomarańczowa, rys. 7b) przy jeszcze zamkniętym wtryskiwaczu (okres od 1,0 do 1,5 ms) - prędkość przepływu gazu na wylocie z przewodu osiąga około $50 \mathrm{~m} / \mathrm{s}$. Wynika to $\mathrm{z}$ chwilowej różnicy ciśnień $\mathrm{w}$ kolektorze dolotowym a przewodem gazowym (oscylacje ciśnienia wynikające z cyklicznego napełniania silnika). Widoczne jest to również, ale w znacznie mniejszym stopniu, w punkcie pomiarowym w przewodzie gazowym (linia zielona rys. 7b), gdzie ruch gazu jest dużo wolniejszy - prędkość wynosi około $13 \mathrm{~m} / \mathrm{s}$.

W chwili rzeczywistego otwarcia wtryskiwacza, czyli około 1,5 ms, można zauważyć niemal równoczesne rozpoczęcie przepływu gazu przez zawór i przez dyszę. Przebiegi prędkości (rys. 7) pod zaworem oraz w dyszy wtryskowej są bardzo podobne do siebie - około 1,7 ms. Po upływie 0,3 ms od rozpoczęcia przepływu $(1,8 \mathrm{~ms})$ gaz dociera do końca przewodu wtryskowego.

Po następnych $0,6 \mathrm{~ms}(2,4 \mathrm{~ms}$ od początku sygnału sterującego) następuje stabilizacja przepływu gazu przez układ (rys. 6 i 7). Widoczne jest to w stabilizacji zarówno ciśnień w poszczególnych punktach pomiarowych, jak i prędkości przepływu. Gaz w układzie przepływa z dużymi prędkościami uzyskując $430 \mathrm{~m} / \mathrm{s}$ w dyszy, $300 \mathrm{~m} / \mathrm{s} \mathrm{w}$ zaworze oraz $210 \mathrm{~m} / \mathrm{s} \mathrm{w}$ punkcie pomiarowym w przewodzie gazowym. Jednocześnie można zauważyć, że w samym przewodzie następuje rozprężenie gazu (spadek ciśnienia między punktem pomiarowym a końcem przewodu), a przez to przyspieszenie gazu, które na końcu przewodu (wejściu do kolektora dolotowego) osiąga wartość $355 \mathrm{~m} / \mathrm{s}$.

W czasie od 6 do $10 \mathrm{~ms}$, odpowiadającym końcowej fazie stabilnego otwarcia wtryskiwacza, widoczny jest spadek ciśnienia oraz prędkości przepływu wewnątrz wtryskiwacza (linia niebieska, rys.6a i 7a). Wynika to ze spadku ciśnienia na wejściu do wtryskiwacza (rys. 6, linia zielona). Prawdopodobnie jest to efekt zbyt małej objętości przewodów doprowadzających gaz do wtryskiwacza lub zjawisk falowych występujących w tym przewodzie w wyniku cyklicznej pracy zaworu, bądź też obydwu zjawisk jednocześnie.

Podobnie jak w przypadku otwierania, również w trakcie zamykania wtryskiwacza zaobserwowano zwłokę czasową wynoszącą około 2,0 ms. Początek ruchu klapy zaworu rozpoczyna się po około $1 \mathrm{~ms}$ od wyłączenia sygnału sterującego, co widoczne jest w minimum lokalnym ciśnienia pod zaworem (linia niebieska, rys. 6c). Zwłoka ta wynika z czasu potrzebnego do rozładowania energii zgromadzonej w cewce. 
a)

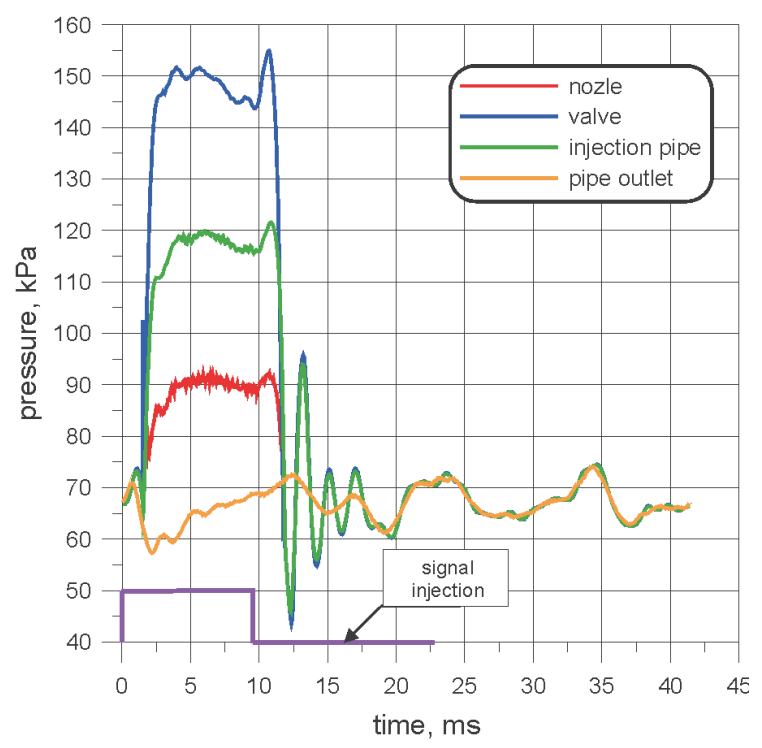

b)

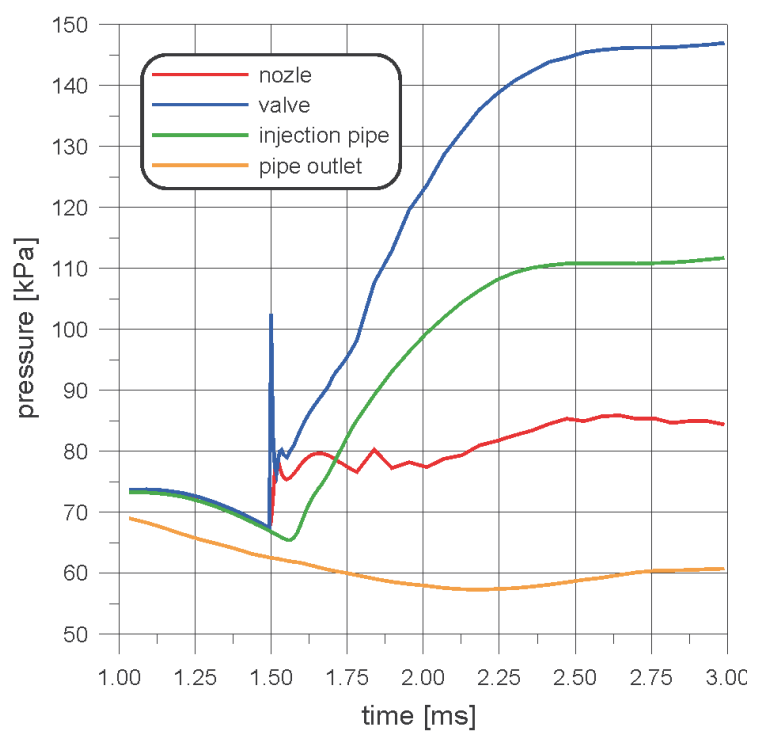

c)

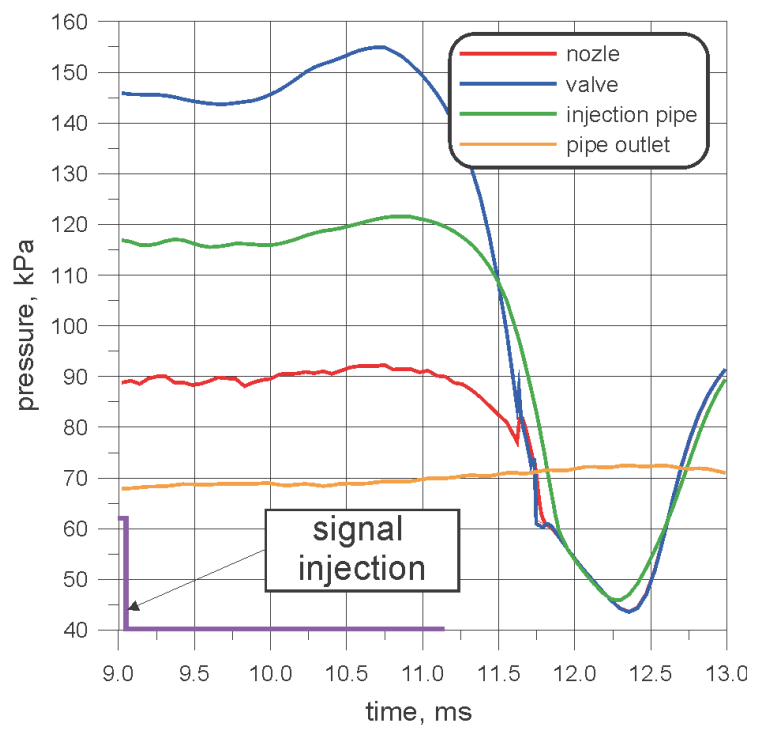

Fig. 6. Pressure course at test points

Rys. 6. Przebiegi ciśnienia w punktach pomiarowych a)

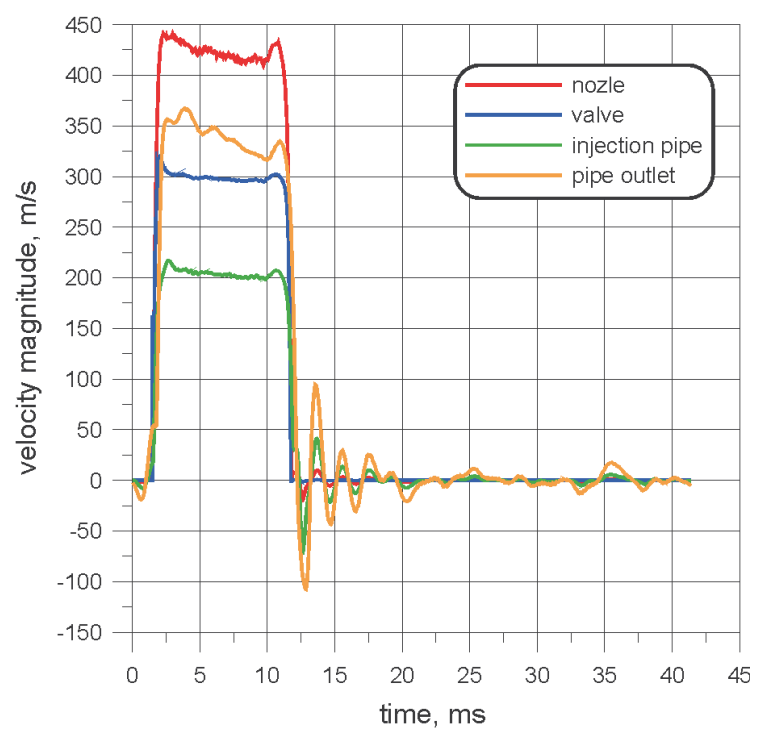

b)

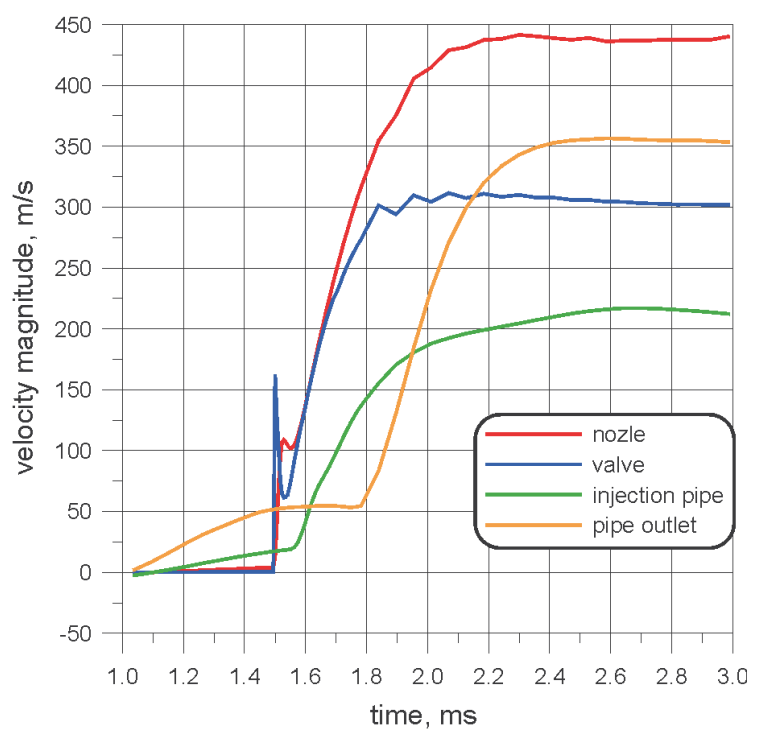

c)

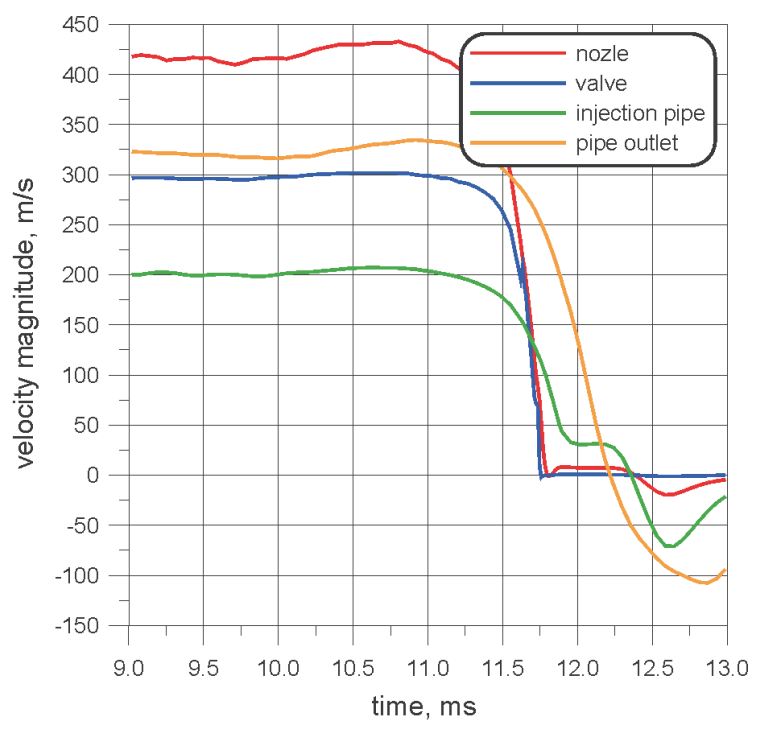

Fig. 7. Velocity at test points

Rys. 7. Przebiegi prędkości w punktach pomiarowych 
A similar pressure increase was observed in the injection pipe (green line, Fig. 6c). The most probable reason for this increase is the pressure change effect in the valve (blue line, Fig. 6c), transferred by the nozzle (red line, Fig. $6 \mathrm{c}$ and $7 \mathrm{c}$ ).

Analyzing the flow velocity during the opening and closing of the injector (Fig. $7 \mathrm{~b}$ and $7 \mathrm{c}$ ) it is clearly seen that the injection nozzle is the element determining the flow size. For both the opening and the closing of the valve the flow velocity in the nozzle (red line) is always the highest. This fact results from the design of the injector- the size of the ducts in the system: the valve, the volume below the valve and the nozzle.

For $0.5 \mathrm{~ms}$ after closing of the valve the gas flows from the injection pipe into the manifold. Because of the dynamic gas flow the end of the injection generates a pulsation in the injection pipe. It may be observed in the back flows (negative velocity outflow orange line, Fig. 7a) at the pipe outlet. In this case the pulsation includes three cycles of a decreasing amplitude. It significantly influences the pressure changes inside the injection pipe (Fig. 6a, green line, time 12-20).

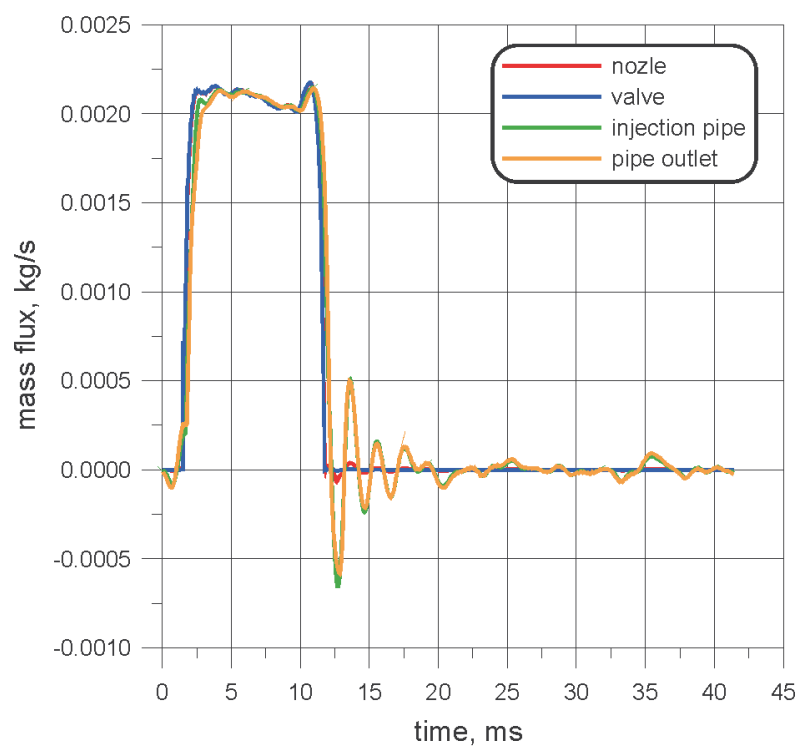

Fig. 8. Mass flow

Rys. 8. Masowe natężenie przeptywu

The above-mentioned processes may appear in the case of mass flow rate (Fig. 8). The back flows are particularly visible here after closing of the injector damping for about 6 $\mathrm{ms}$. The mean flow rate through this system is $2.1 \mathrm{~g} / \mathrm{s}$ during full valve opening.

Figure 9 presents the pressure distribution and the flow velocity in the A-A injector cross-section. One can notice that during the opening an area of the maximum flow velocity moves from the valve (time $1.8 \mathrm{~ms}$ ) towards the nozzle (time 2.0). Then, it stays there for the rest of the time of the opening of the valve. Therefore, the nozzle remains the main element determining the flow.

At the beginning of the injection the pressure is the same in the whole injector. After opening it drops locally in the
Następujący potem wzrost ciśnienia w tym punkcie jest wynikiem ruchu klapy wtryskiwacza w kierunku zaworu. Maksimum tego wzrostu występuje w chwili zamknięcia zaworu, czyli po około 1,7 ms od chwili wyłączenia sygnału sterującego.

Zaobserwowano także podobny wzrost ciśnienia w przewodzie wtryskowym (linia zielona, rys. 6c). Prawdopodobną przyczyną tego wzrostu jest oddziaływanie zmian ciśnienia na zaworze (linia niebieska, rys. 6c), przenoszone przez dyszę (linia czerwona, rys. 6c i 7c).

Przy analizie prędkości przepływu podczas otwierania i zamykania wtryskiwacza (rysunki 7b i 7c) widoczne jest, że dysza wtryskowa jest cały czas elementem determinującym wielkość przepływu. Zarówno przy otwieraniu, jak i zamykaniu zaworu prędkość gazu w dyszy (linia czerwona) jest zawsze największa. Zjawisko to wynika z konstrukcji wtryskiwacza - przekroje i objętości kanałów w układzie: zawór, objętość pod zaworem i dysza.

Przez około 0,5 ms po zamknięciu zaworu występuje wypływ gazu z przewodu wtryskowego do kolektora dolotowego. Ze względu na zjawiska dynamiczne przepływu gazu, zakończenie wtrysku generuje w przewodzie wtryskowym pulsację. Widoczne jest to w przepływach zwrotnych (ujemna prędkość wypływu - linia pomarańczowa, rys. 7a) na wyjściu z przewodu. W badanym przypadku pulsacja obejmuje trzy cykle o zmniejszającej się amplitudzie. Wpływa to w znaczny sposób na zmiany ciśnienia wewnątrz przewodu wtryskowego (rys. 6a, linia zielona, czas 12-20 ms).

Wyżej wymienione zjawiska można zauważyć także na masowym natężeniu przepływu (rys. 8). Szczególnie widoczne są tu przepływy zwrotne po zamknięciu wtryskiwacza gasnace przez około $6 \mathrm{~ms}$. Średni strumień przepływu przez ten układ w okresie pełnego otwarcia wtryskiwacza wynosi około $2,1 \cdot 10^{-3} \mathrm{~kg} / \mathrm{s}$.

Na rysunku 8 przedstawiono rozkłady ciśnienia i prędkości przepływu w przekroju A-A wtryskiwacza. Można zauważyć, że podczas procesu otwierania obszar maksymalnej prędkości przepływu przemieszcza się od zaworu (czas 1,8 ms) do dyszy (czas 2,0 ms). Następnie utrzymuje się w niej przez cały pozostały czas otwarcia zaworu. Dysza stanowi zatem główny element determinujący natężenie przepływu.

Na początku wtrysku ciśnienie w całej objętości wtryskiwacza jest jednakowe. Po otwarciu zaworu spada ono jedynie lokalnie w obszarze samego zaworu. Po czasie 0,3 ms od początku ruchu zaworu (czas 1,8 ms) ciśnienie bezpośrednio pod zaworem spada o prawie $0,1 \mathrm{MPa}$ powodując, że prędkość przepływu gazu w tym obszarze zwiększa się do ponad $270 \mathrm{~m} / \mathrm{s}$. Tworzy się tutaj strumień przepływu o średnicy znacznie mniejszej niż średnica przewodu pod zaworem, widoczny na rysunku w postaci „, tezki” lokalnego zwiększenia prędkości przepływu. Maksymalna prędkość w tym rejonie dochodzi do $370 \mathrm{~m} / \mathrm{s}$. W miarę otwierania zaworu przekrój strumienia zwiększa się, obejmując cały kanał pod zaworem, co powoduje spadek prędkości przepływu do poziomu około $280 \mathrm{~m} / \mathrm{s}$ w czasie $2,4 \mathrm{~ms}$ od początku sygnału sterującego. Przepływ w tym rejonie ustala się stosunkowo 


\begin{tabular}{|c|c|c|c|}
\hline Static pressure/Ciśnien & atyczne & Flow velocity/Prędkośc & eplywu \\
\hline \multicolumn{4}{|c|}{$1,6 \mathrm{~ms}$} \\
\hline 1 & 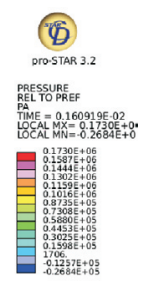 & ד & 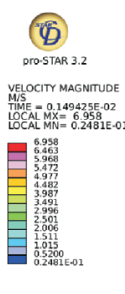 \\
\hline \multicolumn{4}{|c|}{$1,8 \mathrm{~ms}$} \\
\hline & 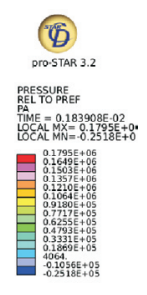 & & 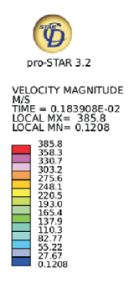 \\
\hline \multicolumn{4}{|c|}{$2,0 \mathrm{~ms}$} \\
\hline & 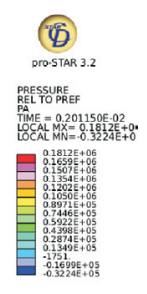 & & 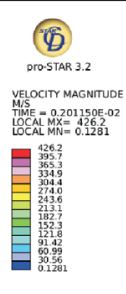 \\
\hline \multicolumn{4}{|c|}{$2,2 \mathrm{~ms}$} \\
\hline & 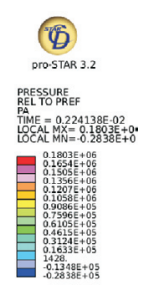 & & 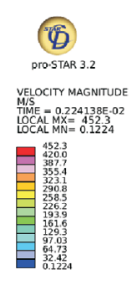 \\
\hline \multicolumn{4}{|c|}{$2,4 \mathrm{~ms}$} \\
\hline$]_{1}$ & 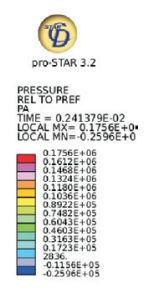 & & 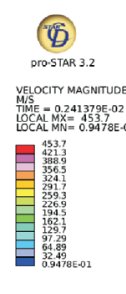 \\
\hline
\end{tabular}

Fig. 9. Static pressure and flow velocity distribution Rys. 9. Rozkład ciśnienia statycznego oraz prędkości przeptywu 
area of the valve. After $0.3 \mathrm{~ms}$ from the valve movement (time $1.8 \mathrm{~ms}$ ) the pressure drops by approx. $0.1 \mathrm{MPa}$ directly below the valve causing gas acceleration to about $270 \mathrm{~m} / \mathrm{s}$ in this area. A flow stream forms here with the diameter smaller than the pipe diameter below the valve, which is seen in the picture in the form of "a tear" of the local increase of the flow velocity. The maximum velocity reaches $370 \mathrm{~m} / \mathrm{s}$ in this area. The flow area spreads as the valve opens, including the whole duct below the valve, which causes the flow velocity to drop to $280 \mathrm{~m} / \mathrm{s}$ in the time of $2.4 \mathrm{~ms}$ from the onset of the control signal. The flow in this area stabilizes relatively fast because after $0.5 \mathrm{~ms}$ (time $2.0 \mathrm{~ms}$ ) both the pressure and the velocity flow are stable. It means that the flow stabilizes in this time in the whole injector.

It is also seen that $0.3 \mathrm{~ms}$ after the valve opening (1.8 ms) de Laval nozzle occurs - in the nozzle area the pressure is lower than in the surrounding points. The pressure drops even below atmospheric pressure. The highest velocity flow occurs here of $426 \mathrm{~m} / \mathrm{s}$ in the case of a steady flow. This velocity equals the velocity of sound.

Analyzing the distribution of the flow velocity and pressure in the injector cross section (Fig. 10 and 11) one can notice that the gas flows mainly in the area between the gas inlet and the valve surrounding. A significant velocity flow of $22-25 \mathrm{~m} / \mathrm{s}$ occurs at the inlet of the injector, which changes within the valve from 17 to $40 \mathrm{~m} / \mathrm{s}$. As a consequence of the axial movement of the valve relative to the axis of the gas inlet a characteristic whirl forms. The gas flow is not homogenous because the highest velocity and the lowest

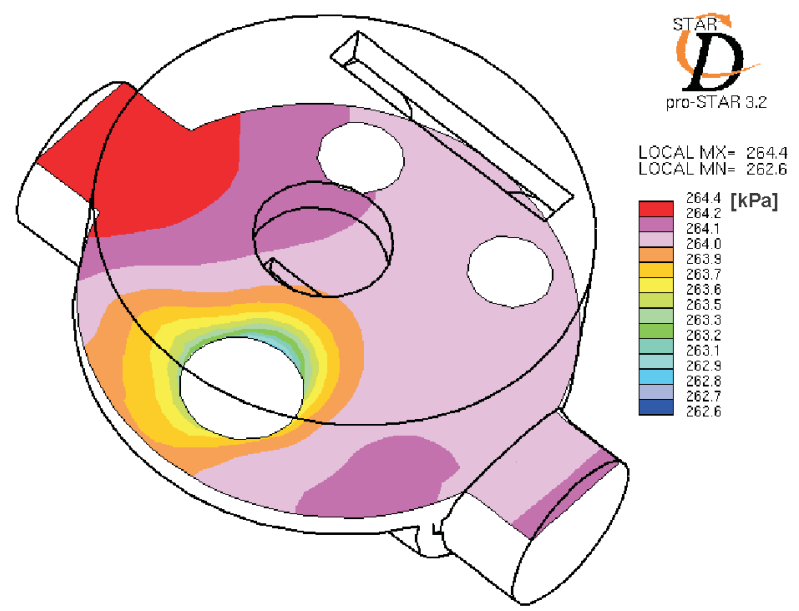

Fig. 10. Pressure distribution in the cross section of injector

Rys. 10. Rozkład ciśnienia w przekroju poprzecznym wtryskiwacza

pressure occur near the axis of the inlet hole (point A). The highest pressure and the lowest velocity appears in point B. It is necessary to mention that the differences in the pressure inside the injector are minisculoe and do not exceed $2 \mathrm{kPa}$.

Moreover, some „dead" zones may be observed where the highest pressure occurs and the flow velocity equals almost zero. However, these areas are not close to the valve, hence no influence on the injection process takes place. szybko, gdyż już po około 0,5 ms (czas 2,0 ms) zarówno ciśnienie, jak i prędkość przepływu są stabilne. Oznacza to, że w tym czasie następuje ustabilizowanie przepływu w całym wtryskiwaczu.

Można także zauważyć, że 0,3 ms po otwarciu zaworu (1,8 ms) pojawia się zjawisko dyszy de Lawala - w obrębie dyszy występuje niższe ciśnienie niż w otaczających je punktach. Ciśnienie to spada nawet poniżej ciśnienia otoczenia. Występuje tu największa prędkość przepływu w całym układzie wynosząca do $426 \mathrm{~m} / \mathrm{s}$ w przypadku stanu ustalonego przepływu. Prędkość ta jest równa prędkość dźwięku.

Analizując rozkład ciśnienia i prędkości przepływu w przekroju poprzecznym wtryskiwacza (rys. 10 i 11), można zauważyć, że gaz przepływa głównie w obszarze pomiędzy wlotem gazu a otoczeniem zaworu. Na wlocie do wtryskiwacza występuje znaczna prędkość przepływu gazu wynosząca około 22-25 m/s, która następnie zmienia się w obrębie zaworu od około 17 do $40 \mathrm{~m} / \mathrm{s}$. W wyniku przesunięcia osiowego zaworu względem osi dolotu gazu tworzy się charakterystyczny wir. Nie jest on jednorodny, gdyż największa prędkość i najniższe ciśnienie występuje najbliżej osi otworu zasilającego (punkt A). Najwyższe ciśnienie i najmniejsza prędkość występuje w punkcie B. Należy jednak zaznaczyć, że różnice ciśnień wewnątrz wtryskiwacza są nieznaczne $\mathrm{i}$ nie przekraczają $2 \mathrm{kPa}$.

Zaobserwowano również kilka stref „,martwych”, gdzie występuje najwyższe ciśnienie oraz prawie zerowa prędkość przepływu. Obszary te nie są jednak w pobliżu zaworu, zatem nie wpływają na przebieg procesu wtrysku.

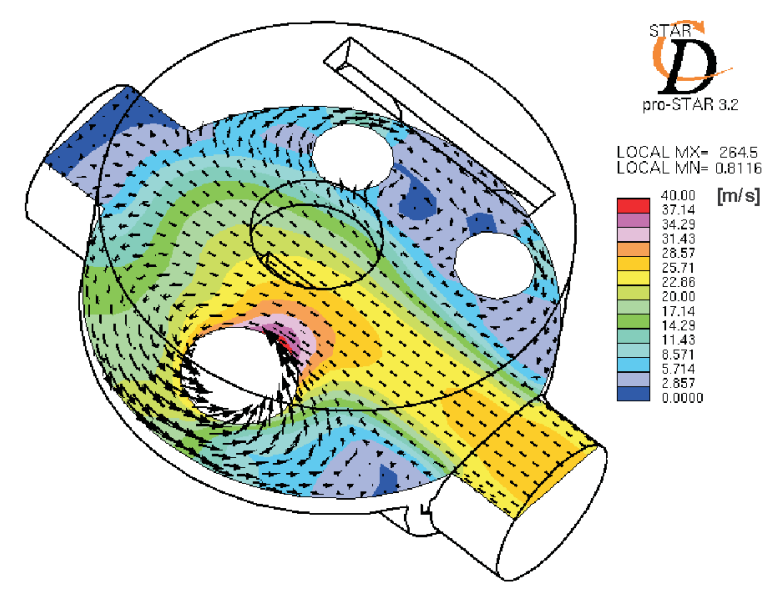

Fig. 11. Velocity in the cross section of injector Rys. 11. Rozkład prędkości w przekroju wtryskiwacza

\section{Podsumowanie}

Przeprowadzone badania symulacyjne przy zastosowaniu metody obliczeniowej CFD umożliwiają analizę zjawisk zachodzących wewnątrz wtryskiwacza gazu zarówno w stanach ustalonych, jak i podczas jego otwierania i zamykania. Pozwala to na określenie istotnych dla konstrukcji obszarów wtryskiwacza oraz wskazanie przyczyn zaobserwowanych zjawisk. 


\section{Summary}

The simulation tests using the CFD method enable the analysis of processes occurring inside a gas injector both in steady states and during its opening and closing. It allows to determine the areas of the injector significant in terms of its design and to point the reasons for the observed processes.

The areas essential for the usable parameters of the injector are: the area below the flap valve and the injection nozzle. The first area determines the flow at smaller flow velocity (variable conditions) and the second one at higher velocity (steady conditions).

The results of this analysis leads to a conclusion that the space above the flap valve inside the injector is properly designed. It is proved by a slight pressure drop between the gas inlet and the area surrounding the valve injector and a fast flow stabilization after the opening of the injector.

The maximum flow velocity inside the nozzle means that the capacity is regulated only by the change of the nozzle diameter and this cross-section determines the characteristics of the capacity.

The application of the injection pipe causes a delay in the initiation of the gas flow into the inlet manifold relative to the beginning of the injector opening and extension of the outflow period.

\section{Bibliography/Literatura}

[1] Boyan X., Furuyama M.: Jet characteristics of CNG injector with MPI system, JSAE Review 19 (1998).

[2] Hountalas D.T., Kouremenos A.D.: Development of fast and simple simulation model for the fuel injection system of diesel engines, Advansedin Enginering Software, vol. 26, No. I, pp. 13-28, 1998.

[3] Hu Q., Wu S.F., Stottler S., Raghupathi R.: Modelling of dynamic responses of an automotive fuel rail system, part I: injector, Journal of Sound and Vibration (2001) 245(5).

[4] STAR-CD Manuals (2004) Ver.3.24 Computational Dynamics Ltd.

Mr. Piotr Jakliński, DEng. - doctor in the Department of Thermodynamics, Fluid Mechanics and Aircraft Propulsion, Lublin University of Technology.

Dr inż. Piotr Jakliński - adiunkt w Katedrze Termodynamiki, Mechaniki Plynów i Napędów Lotniczych Politechniki Lubelskiej.

e-mail:p.jaklinski@pollub.pl

Mr. Konrad Pietrykowski, MEng. - PhD student in the Department of Thermodynamics, Fluid Mechanics and Aircraft Propulsion, Lublin University of Technology.

Mgr inż. Konrad Pietrykowski-doktorant w Katedrze Termodynamiki, Mechaniki Plynów i Napędów Lotniczych Politechniki Lubelskiej.

e-mail: k.pietrykowski@pollub.pl
Przekrojami istotnymi dla parametrów użytecznych wtryskiwacza są: przekrój pod zaworem klapowym oraz przekrój dyszy wtryskowej. Pierwszy determinuje przepływ przy mniejszych prędkościach przepływu, czyli w stanach nieustalonych, natomiast drugi przy większych, czyli w stanach ustalonych.

Analiza wyników wykazała, że przestrzeń nad zaworem klapowym wewnątrz wtryskiwacza jest odpowiednio zaprojektowana. Świadczy o tym nieznaczny spadek ciśnienia pomiędzy wlotem gazu a obszarem wokół zaworu wtryskiwacza oraz szybkie ustabilizowanie przepływu po otwarciu wtryskiwacza.

Występowanie maksymalnej prędkości wewnątrz dyszy wtryskowej oznacza, że regulacja wydatku wtryskiwacza odbywa się jedynie przez zmianę średnicy dyszy wtryskowej, a przekrój dyszy determinuje nachylenie charakterystyki wydatku wtryskiwacza.

Zastosowanie przewodu wtryskowego wiąże się z występowaniem opóźnienia początku wypływu gazu do kolektora dolotowego względem początku otwarcia wtryskiwacza oraz wydłużeniem okresu wypływania.

\section{Artykut recenzowany}

[5] Wendeker M., Jakliński P., Czarnigowski J., Rola M., Grabowski Ł., Pietrykowski K.: CFD model of fuel rail for LPG systems, SAE Technical Paper 2007-01-2053 (2007).

[6] Wendeker M., Jakliński P., Grabowski Ł., Pietrykowski K., Czarnigowski J., Hunicz J.: Model klapowego wtryskiwacza gazu CNG do silników spalinowych", Silniki Spalinowe $4 / 2007$.

Mr. Jacek Czarnigowski, DEng. - doctor in the Department of Machine Design, Lublin University of Technology.

Dr inż. Jacek Czarnigowski-adiunkt w Katedrze Podstaw Konstrukcji Maszyn Politechniki Lubelskiej.

e-mail: j.czarnigowski@pollub.pl

Prof. Mirosław Wendeker, DSc., DEng. - Professor, Head of Department of Thermodynamics, Fluid Mechanics and Aircraft Propulsion, Lublin University of Technology.

Prof. dr hab. inż. Mirosław Wendeker - kierownik Katedry Termodynamiki, Mechaniki Plynów i Napędów Lotniczych Politechniki Lubelskiej.

e-mail:m.wendeker@pollub.pl

Mr. Łukasz Grabowski, MEng. - PhD student in the Department of Thermodynamics, Fluid Mechanics and Aircraft Propulsion, Lublin University of Technology. Mgr inz. Lukasz Grabowski - doktorant w Katedrze Termodynamiki, Mechaniki Plynów i Napędów Lotniczych Politechniki Lubelskiej. e-mail: grabowski@pollub.pl 